\title{
THE DEVELOPMENT OF LINGUISTICS IN KAZAKHSTAN: NEW APPROACHES AND MODERN TENDENCIES
}

\author{
Sholpan Zharkynbekova, Atirkul Agmanova
}

\begin{abstract}
The article represents an overview of some of the research priorities of Kazakhstani scientists who study the linguistic, socio-linguistic, and methodical parameters of scientific description of a language as a social fact. We describe the language situation in Kazakhstan, which creates a scientific background for theoretical and practical understanding of the language changes taking place in the country. The article shows that the common methodological basis of research is a systemic approach to the problem of multilingual space of Kazakhstan, in which different aspects of this complex phenomenon are consistently and purposefully studied from the standpoint of the theoretical provisions on the relationship of language and society. The sociolinguistic studies focus on the identification of the nature and role of languages in ethnocultural interaction. This way this research provides essential information for the timely adjustment of the language policy and language planning and is useful for management tasks in the field of language regulation.
\end{abstract}

Keywords: ethnolinguistic identity, language co-functioning, language planning, language policy, multilingual landscape, sociolinguistics

\section{INTRODUCTION}

Obviously, the modern linguistics of Kazakhstan is characterised by its development in the context of a new scientific paradigm that defines the state, and achievements, of the world linguistic idea.

A particular place is given to the research devoted to language study as one of the main indicators of human adaptation to the new socio-political and sociocultural realities. As Russian scientist Leonid Krysin states, sociolinguistics as a comparatively young science distinguishes nationally oriented research trends, and is connected with the fact that in each country, or more narrowly in each ethno-social community, there are specific conditions for a language functioning, the most important or which become the issues that are topical for this national (or multinational) community (as characterised by the unity of the socio-economic and political life) (Krysin 1992: 96). In this respect it is worth mentioning that for Kazakhstani sociolinguistics it is peculiar to address 
the issues of linguistic and ethnic identification, preserving ethnical languages in the multilingual state, cross-cultural communication, and ethno-linguistic adaptation. Much interest causes problems in the functioning and interaction of the Kazakh, Russian, and English languages in the modern multilingual landscape of Kazakhstan, and in more effective ways of multilingual personality formation. Of course, these aspects do not comprise the whole range of the studied problems. We have limited our research to a few areas that reflect the current trends of Kazakhstani sociolinguistic science.

\section{LINGUISTIC AND EXTRA-LINGUISTIC BASES}

The functioning of two or more languages in the context of the modern Kazakhstani sociolinguistic space allows us to speak about the uniqueness of the situation, related as it is to a targeted official language policy that promotes the idea of the multilingualism (trilingualism) of the citizens of the Republic of Kazakhstan as one of the most important conditions of social and economic modernisation.

The Republic of Kazakhstan is a multilingual state with representatives of more than 130 ethnic groups. According to the results of the 2009 census, the ethnic composition of Kazakhstan is as follows: Kazakhs $-63.1 \%$, Russians $23.7 \%$, Uzbeks - 2.9\%, Ukrainians - 2.1\%, Uighurs - 1.4\%, Tatars - 1.3\%, Germans $-1.1 \%$, Koreans $-0.6 \%$, Turks $-0.6 \%$, Azeri $-0.5 \%$, Belarusians $-0.4 \%$, Dungan $-0.3 \%$, Kurds $-0.2 \%$, Tajiks $-0.2 \%$, Poles $-0.2 \%$, Chechens $-0.2 \%$, Kyrgyz $-0.1 \%$, others $-1.1 \%$ (Smailov 2010: 10). It should be noted that the most numerous nationalities are Kazakh (10.1 million people) and Russian (3.8 million people).

This demographic situation of the country is linked to the history of migration of other peoples to Kazakhstan during the Soviet period. From the early twentieth century to the nineteen-nineties there were major demographic transformations in the ethnic composition of Kazakhstan. These changes were associated primarily with the former Soviet policy of forcible deportation of peoples between 1930 and 1950, the famine of 1931-1932, repression of the Kazakh elite in the late 1930s, and labour migration, mainly of Slavic ethnic groups (Russians, Ukrainians, and Belarusians), who formed the backbone of the minorities. Some of them were deported during the Second World War, others have lived in the territory of Kazakhstan for centuries (Sancak \& Finke 2005: 132). The total number of members of the different ethnic groups deported to Kazakhstan in the years 1930-1940 was 1.2 million. During the period of industrialisation and development of virgin lands, about 2 million people im- 
migrated to Kazakhstan, which significantly modified the ethnic composition of Soviet Kazakhstan. At the same time, more than a million Kazakhs emigrated because of repression, famine, collectivisation, and other causes. According to official census data, the population in the country decreased from 3.63 million people in 1926 to 2.31 million people in 1939 .

The phenomenon of mass bilingualism (the ratio of the Kazakh-Russian bilingualism and Russian-Kazakh bilingualism) with a lower Kazakh language proficiency is explained by the influence of historical and political factors, and especially the widespread policy of Russification carried out in the Soviet period. The Russification policy, proclaiming Russian as the language of international communication, changed the linguistic landscape of Soviet Kazakhstan. According to B. Dave and P. Sinnott (2002: 5-8), the so-called "Russified cultural landscape" dominated in Kazakhstan. In 1938, Russian was declared a compulsory subject in all schools including non-Russian schools (Suleimenova 1997). Russian was perceived as a prestigious language, the language of higher education. The presence of this historical fact still significantly influences the growth rate of national consciousness and self-awareness in Kazakhstani society, despite the state's gained independence. According to E. Suleimenova (ibid.), "in those conditions changes appeared in the relationship between the Kazakh and Russian languages when the ethnic, cultural, and linguistic identity was seen as formal by a certain part of the population". She concludes that the decline in the prestige of Kazakh culture, identity, and history was related to the low prestige of the Kazakh language. The result was passive skills in the native language and the adoption of Russian by a part of the Kazakh population. "Kazakh was forced out of the public sphere and business communication", and in practice the "functional health' and 'communicative power' of Kazakh" decreased (Suleimenova \& Smagulova 2005: 70).

The process of integration into the world community, access to modern technology, and the need to implement the results and achievements of the world of science and education in the sustainable development of a country today requires the mastering of English and other foreign languages and an improvement in their level of knowledge.

Increased attention to linguistic processes in Kazakhstan is supported by the adoption of the law on languages, ${ }^{1}$ the emergence of television and radio programmes on language themes, conferences, workshops, and scientific seminars, publication of topical articles, research, etc. Therefore, the study of a language as one of the main indicators of the population's adaptation to the new socio-political and socio-cultural realities has become an urgent theoretical and practical task. 
The above confirms the need for a theoretical and practical understanding of the linguistic changes occurring in the country. Based on the analysis of active ethno-linguistic processes and value priorities of a language, scientists are trying to rethink the traditional concepts of language policy and linguistic situation established in the period of independence.

\section{THE METHODOLOGICAL BASES OF THE RESEARCH}

The studies included in this review article are characterised by being generally uniform in their objectives, theoretical orientation, and methods of analysis of the linguistic material. Their common methodological basis is a systematic approach to the problem of the multilingual space of Kazakhstan, in which different sides of this complex phenomenon are consistently and purposefully considered from the perspective of the theory of the relationship between language and society, studying the specific peculiarity and the identity of languages and cultures, and priority issues which shape public consciousness under the influence of certain linguistic and extra-linguistic factors.

For the majority of the research, the discursive approach is used as a paradigm of studying functional languages within a broad socio-cultural context. The interdisciplinarity of the research is reflected in the approaches to the studied phenomena, and also in the methods and interpretations. In addition to general scientific methods (inductive, deductive, simulation, comparative, etc.), interdisciplinarity is used as a range of socio-linguistic methods to obtain an in-depth and comprehensive analysis of the following:

- the method of monitoring used for the selection process, to determine specific features of the investigated object, to describe different linguistic situations and trends in the development of various linguistic situations and tendencies within cross-cultural communication development;

- the method of social experiment, where polls, discussions, study, and generalisation in specific socio-situational contexts have great potential to track processes of language functioning;

- qualitative methods, which can study the life of small groups in which the standards of social identification and bases for ethnic identity are formed;

- the methods of experimental research, i.e. group and individual questionnaires, content-analysis, monitoring the speaking activity in various spheres of public life, and the study of written resources and official documents; 
- the statistical analysis of data reference of information (including electronic) using SPSS Statistics Programme.

The methodology of this research allows us to ensure the introduction of multilingualism in the Republic of Kazakhstan, as well as the implementation of the priorities of the State Programme for the Functioning and Development of Languages for 2011-2020.

\section{Linguistic and Ethno-Linguistic Identities:}

\section{Theory, Results, and Research Prospects}

The works of Kazakhstani linguists revealed in detail various aspects of national and Russian bilingualism, within the framework of which was an investigation into the issues of ethno-cultural self-identification, linguistic identification related to language choice in a bilingual person, and the role of the mother tongue in these processes (Khasanov 1992, 2001; Khasanuly 1992, 2002; Kopylenko \& Saina 1982; Kopylenko 1997; Karlinskii 1989, 1990, 2001; Suleimenova 1996, 2007, 2011a, 2011b; Suleimenova \& Smagulova 2005; Suleimenova et al. 2007; Isaev 1990; Akhmetzhanova 2001; Tezekbayev 1987, 1998; Son 1999; Pak 2004; Altynbekova 2006; Shaibakova 1999).

Recent work that represents the lines of research into identity issues at the present stage deserves a detailed review.

The general context of research into the linguistic aspects of identity study is linked to the analysis of dynamic processes of ethnic and linguistic identification, the main trends of civic identity change, and the 'crisis of identity' in the multiethnic Kazakhstan.

In some researches the problems of linguistic and ethnic identity have been examined in terms of a language choice in education, the language of the diaspora, the peculiarities of the speech behaviour of a particular ethnic group, stereotypes of national character, peculiarities in the formative years of a bilingual person in the process of second language acquisition (Altynbekova 2006; Son 1999; Pak 2004; Agmanova 2010, and others).

Olga Altynbekova (2006) considers the choice of the language of instruction in schools and universities to be an indicator of the expression of the ethnic identity of different nationalities in a multiethnic society.

Issues of linguistic and ethnic identity are investigated by Atirkul Agmanova (2010) as part of her description of the extra-linguistic factors that influence the acquisition and use of Kazakh as a second language. The sociolinguistic part of the study allowed the linking of the predicate-centric theory of a second- 
language acquisition developed by the author with the experience and results of language planning in the fields of education and the state.

Professor E. Suleimenova conducted a series of research investigations which reflected the issues of linguistic, ethnic, and civic identities of different social groups within Kazakhstan.

The results of this research were reflected in the collective monograph titled Dinamika iazykovoi situatsii v Kazakhstane (The Dynamics of the Linguistic Situation in Kazakhstan) (Suleimenova 2010d). This research compared collected data with previous surveys from 2003 and 2005, in order to study different aspects of national, ethnic, and linguistic identification at the individual level and their correlation to the attitudes toward language in the dynamically developing Kazakh society. The collective monograph also presented an analysis of how the civic and linguistic identity of the respondents and their integration into Kazakhstan's society is related to ethnicity, social factors, and age (ibid.).

E. Suleimenova has devoted a number of research papers to the study of the essential manifestations of linguistic and ethnic identity and the features of their modification and development in a rapidly changing linguistic situation among dynamic ethno-demographic processes. On the basis of the theoretical comprehension of identity variability thesis she concludes:

Linguistic identity as any other identity is not something attributing and congenital but is an individual's interiorised characteristic, which can be chosen by expressing in linguistic and socio-cultural behaviour, or changed depending on social, political and ideological contexts. (Suleimenova 2010a: 125)

Linguistic identification is defined as "a constant process of enculturation and integration of the individual into society". Language "helps the individual to socialise, acquire cultural and social norms, and support the relations within ethnic, age, gender, social role, and other groups" (ibid.: 126).

Particular attention in Suleimenova's research is given to the issue of mobility of ethnic and linguistic identities among the younger generation (Suleimenova 2007, 2010a).

The ethnic and linguistic identities of the young Kazakh and Russian respondents were studied from the following points of view:

- correlation of ethnic and linguistic identities with the attitude of the young respondents to their mother tongue;

- correlation of ethnic and linguistic identities with the language competence of the young respondents;

- correlation of ethnic and linguistic identities with the fields of Kazakh and Russian language usage by the young respondents; 
- correlation of ethnic and linguistic identities with the attitude (language settings) of the young respondents towards a language/languages.

In the analysis of the correlation between ethnic and linguistic identity and the acceptance of an ethnic language as a native speaker of that language, the Kazakh respondents demonstrate positive dynamics; the Russian respondents demonstrate the opposite, i.e. negative dynamics (in 2009, 0.7\% of Kazakhs considered Russian as their native language, and $2.0 \%$ of Russians defined Kazakh as their native language).

Data on language competence indicate positive dynamics of the processes of linguistic identification taking place in the country: a high proportion of Kazakh respondents (97\%) and Russian respondents (69.8\%) claim to be fluent or have some command of Kazakh. This growing competence is seen as an obvious indication of the formation of the Russian-Kazakh bilingualism in the country.

The following conclusion, made by E. Suleimenova, seems to be reasonable:

There must be consistent, deliberate, and conscious change in the language behaviour of all population groups in order to make the declared ethnic and linguistic identities real. The problem of choice of the existing 'register of identity' of the most appropriate linguistic identity, in accordance with the specific socio-cultural and political circumstances of youth, has to be successfully solved, and the existing general asymmetry in the usage of Kazakh and Russian has to be finally overcome. (Suleimenova 2010a: 164)

The understanding that a complete, comprehensive study of linguistic identity in a polynational state is impossible without considering its complicated interaction with the processes of ethnic and civil identification, contributed to the development of civic identity, determining the main vector of its changes in the formation and development of independent Kazakhstan.

In order to define the content of dynamics and trends within civil identity, Suleimenova studied its two important aspects in the work titled The Main Vector of Civil Identity (Suleimenova 2010c): a) the extent and character of civil identity; b) the peculiarities of the diffusion of civil identity considered from the point of view of its correlation with the respondents' ages and genders.

The results of the study suggest a conclusion about the obvious positive changes in the understanding of civic identity as the basis of state stability and the consolidation of Kazakh society. It was convincingly proved that there was an obvious increase in civic identity indices (9.3\%) during the studied period (according to the survey data in 2005 and 2009 respectively), which in the context of the two major ethnic groups is represented as follows: Kazakh respondents $-90.6 \%$ and $98.5 \%$; Russian respondents $-86.6 \%$ and $95.4 \%$. The 
Tatar, Ukrainian, German, Belarusian, Korean, Polish, Chechen, and Armenian respondents demonstrated complete formation of a Kazakhstani civil identity, while the Kyrgyz, Uzbek, and Uighur respondents demonstrated a decrease in these parameters through a redistribution of the answers in the category titled "I partially consider myself a citizen of Kazakhstan".

The diffuse civic identity of an insignificant number of respondents was revealed within the context of high levels of awareness of these people (from different age groups) as citizens of Kazakhstan (Suleimenova 2010b: 235-237).

In a multilingual society, "linguistic identification is complicated by the choice of one of the co-functioning languages and the necessity of continuously determining one's own attitude to those languages and mobile self-assessment of language behaviour" (Suleimenova 2011b: 181). What Suleimenova calls the "crisis of identities", can be due to the following factors: conflict between ethnic and linguistic identities; switching from one linguistic identity to another, more relevant at a particular time and in a particular place (for example, because of a change of language status); language change by an ethnic group; the preservation of stereotypes by part of a community despite a change of priorities in society at large.

It should be noted that the study of the dynamics of the crisis in ethnic and linguistic identity, within the context of social and ideological transformation, is based on a comparison of sociolinguistic research data received in five-year intervals, which made it possible to fully comprehend the problem (Suleimenova 2010b).

The crisis of ethnic and linguistic identity, perceived among respondents of different ethnic, age, and gender groups is studied in the following aspects:

- the crisis of ethnic and linguistic identity among the Kazakh respondents;

- the crisis of ethnic and linguistic identity among the Russian respondents;

- the crisis of ethnic and linguistic identity among the Tatar, Ukrainian, and German respondents;

- the crisis of ethnic and linguistic identity among the different age groups of the Kazakh respondents;

- the crisis of ethnic and linguistic identity among gender groups of the Kazakh respondents.

The dynamics of the crisis of ethnic and linguistic identity revealed in the study were generally evaluated to be positive, as it seems Kazakhstan has been successful in overcoming the crisis: 1) a general tendency was noted of an equalising correlation of ethnic and linguistic identity over five years for the two groups of respondents - the Kazakh and the Russian (indicators of Kazakh and Russian linguistic identities increased by $6.8 \%$ and $4.8 \%$, respec- 
tively); 2) the dependence of linguistic identity on linguistic competence was noted among respondents from some ethnic groups: a) full (Ukrainian and German respondents) or partial (Korean, Chechen, and Belarusian respondents) recognition of the Russian linguistic identity, and b) the index growth of the Kazakh linguistic identity of the Tatar, Uighur, and Belorussian respondents; 3 ) there is a reduction in the gap between the ethnic and linguistic identities of the Kyrgyz, Polish, Armenian, and Uzbek respondents.

This research certainly contributes to the development of empirical data and a deepening of the study of linguistic and ethnic identity in modern Kazakhstan. The findings are important both for a theoretical understanding of the problem, and because they contribute to the practice of language planning and language development.

The considered findings above are similar to the study results of Kazakhstani linguists, which focused on the problems concerned with diaspora language description, its function in the social and communicative space of the country, and the study of the linguistic and ethnic identities of ethnic groups. The researchers' attention to the problem is natural not only because of the diverse ethno-linguistic landscape of Kazakhstan, but also because of the general trend of increasing national consciousness and the desire for revival and preservation of national language and culture. The problem of linguistic and ethnic identity among members of ethnic groups as one of the important aspects in the study of identity in Kazakhstani linguistics was reflected in a number of studies, the focus of which is centred on the issues of diaspora language interaction with Kazakh and Russian. These studies also encompassed information on the functioning of these two languages in the multiethnic and multicultural society, pointing out that this requires the formulation and solution to such problems as native language vitality, language change, and the impact of the processes of change on the processes of linguistic and ethnic identity (Zharkynbekova \& Bokayev 2011; Son 1999; Pak 2004; Gazdieva 2009).

The identity peculiarities of the ethnic Ingush living in Kazakhstan, and the characteristics of the Ingush language in Russian-Kazakh bilingualism, are revealed in Gazdieva's work titled Funktsionirovanie rodnogo iazyka ingushskoi diaspory $v$ usloviiakh russko-kazakhskogo bilingvizma (Functioning of the Ingush Diaspora's Native Language in Russian-Kazakh Bilingualism) (2009). As was evidenced by the study results, long-term Ingush residence in another ethno-linguistic and cultural space in close cooperation with representatives of the Kazakh and Russian people has been expressed in the essential features of their speech and the communicative behaviour of the individual Ingush. The current state of the Ingush diaspora's language was found to be characterised by a constriction in the function in the family and everyday sphere: there are 
also transformations in the ethno-linguistic identity of the Ingush in favour of the state identity, while preserving their own culture and language in the non-national environment (ibid.).

In the study titled Sotsiolingvisticheskii analiz funktsionirovaniia kore mar i russkogo iazyka $v$ koreiskoi diaspore Kazakhstana (Sociolinguistic Analysis of the Functioning of Kore-Mar and Russian Languages in the Korean Diaspora in Kazakhstan), Svetlana Son (1999) attempted to analyse the linguistic situation among Koreans in Kazakhstan from the point of language change and the setting of criteria for language stability in the process of its loss as a functionally first language. It has been proved that correlation between the notions of ethnic and linguistic communities of Koreans can be solved only with the help of language characteristics; a language choice is realised through a complex of factors - demographic, social, political, psychological, cultural, historical, economic, and others (ibid.).

In the past ten years of ethno-demographic processes the issue of the linguistic adaptation of Kazakh repatriates in the - for them - new social and cultural space, and their integration into modern Kazakh society, has been occupying a particular place. This problem is directly connected with the study of the peculiarities of the ethnic, linguistic, and civil identities of the Kazakh repatriates.

In their monograph titled Protsessy iazykovoi $i$ etnicheskoi identifikatsii repatriantov Kazakhstana (Processes of Linguistic and Ethnic Identification of Kazakh Repatriates), Sholpan Zharkynbekova and Baurzhan Bokaev (2011) consider the problem of the adaptation and integration of ethnic Kazakh repatriates into Kazakhstani society through changes in their ethno-linguistic self-consciousness under the influence of the social, historical, and globalised transformations of society and the process of ethno-linguistic identity formation. The study results are based on extensive questionnaire data (carried out in six regions: northern Kazakhstan, eastern Kazakhstan, Mangystau, southern Kazakhstan, Akmola, and Astana city), autobiographical texts, mass media materials, and audio recordings of the live speech of the repatriates.

The respondents, ranging in age from 16 to 60, who had arrived from China, Mongolia, Uzbekistan, Tadzhikistan, Turkmenistan, and Russia, participated in the questionnaire. The following aspects of ethno-linguistic identification of the Kazakh repatriates were considered: 1) the role of native language in the ethnic self-consciousness of Kazakhs; 2) language competence as a reflection of linguistic and ethnic identity; 3) the scope of Kazakh, Russian, and other language usage; 4) the attitude to languages. 
According to the authors' opinion, the Kazakh repatriates demonstrated that for them the Kazakh language and its association with the Kazakh ethnic community has a highly actualised, culturally symbolic meaning.

Based on this study, a sociolinguistic portrait of a repatriate was created. A typology of ethno-linguistic personalities was established for the repatriates in 4 types: Kazakh language speakers and Russian language speakers (foreign language speaking), bilingual repatriates who prefer to speak Russian (or another language), and bilinguals who prefer to speak Kazakh. This typology was built on attitudes towards native language as the main means of communication and as a symbol of ethnic self-identification. The authors state that the absence, or low level, of Kazakh language competence explains the discrepancies between ethnic and linguistic identities and hinders the determination of personal linguistic identity (Zharkynbekova \& Bokaev 2011).

It is worth noting that a comprehensive analysis of the studied issue was successfully implemented in this work due to a complex research programme using well-established methods and techniques (questionnaire, interview, monitoring and analysis of speaking behaviour, associative experiment, the study of written material, and analysis of mass media material aimed at defining the formation of stereotypical ideas about repatriates).

A. Dosanova (2011) in her work introducing the peculiarities of linguistic adaptation of the Kazakh repatriates studying at universities revealed the cases of language bearers and cultural shock in the process of acculturation. Thus, the object of study in this paper is limited to one social group. On the basis of the correlation analysis of mass questionnaire data and focus interviews the following features of the ethnic, linguistic, and civil identities of repatriates were revealed: a) the diffusivity of civil identity (34.6\%), the indirect confirmation of which is contained in the interview, as well as the observed trend "do not rush to get the Kazakhstani citizenship"; b) difficulties of identification processes which hinder a quick integration into a new for them Kazakhstani society and its structures; c) the absence of crisis of ethnic and linguistic identities: the correlation of ethnic and linguistic identities is reflected by the general indexes of the Kazakh language competence, Kazakh language usage in intergeneration and within generation language transmission as well as by attitude towards a language (ibid.: 30).

Thus, the multiethnic culture and multilingual society of Kazakhstan, the specific feature of mentality, and the interests of each ethnic group create a peculiar socio-cultural context of the different aspects of the research problem of identity in modern linguistics.

Inter-ethnic harmony and tolerance - the traditional values of the independent Kazakhstan, the basis of national stability and society consolidation - fa- 
cilitate a harmonious functioning and developing of the languages and cultures of all Kazakhstani ethnic groups. Study of the ethno-linguistic identification processes can define a range of problems that exist in the new language policy today. These problems can be both inherited from the Soviet period and related to the current political and economic situation in the world in general and in the territory of the former Soviet Union in particular. The solution of problems will make it possible to contribute to the realisation of the idea of peaceful coexistence of ethnic groups living in the territory of the Republic of Kazakhstan, and their languages.

The active work of the Assembly of Peoples of Kazakhstan, established on the initiative of the head of state N. Nazarbayev in 1995, supports the diasporas' growing interest in their native language, culture, traditions, and customs, which generally beneficially influence the preservation of the ethnic groups' identity and are consistent with their increased awareness of their ethnic identity.

\section{Research on the co-functioning of Kazakh, Russian, and English languages in the modern multilingual space of Kazakhstan}

Scholars of Kazakhstan are particularly interested in questions of how Kazakh, Russian, and other languages function together at the present stage of development of this multi-ethnic society. One focus of this research is on the readiness of the population to adapt to new social and cultural conditions with the goal of understanding the relationship between the language processes and geographic, ethnic, demographic, and other extra-linguistic factors that influence the linguistic preferences of the population.

Different aspects of Kazakh-Russian bilingualism were widely reflected in the works of Kazakhstani linguists. B. Khasanuly $(1992,2002)$ focused on the essential fields and consistent patterns of the Kazakh and Russian language functions and the issue of native language in the modern linguistic situation. Khasanuly went on to suggest a regional approach to the problem of the functional development of official and regional (national) languages. Investigating the issues of monolingualism, bilingualism, and multilingualism, B. Khasanuly (2002) shows that it would be appropriate to consider the development of official and regional languages in the context of globalisation - south, west, north, east, and central. Considering the regional linguistic situation and factors influencing its change, the regional approach would provide a solution to the issue of study within the republic.

As Khasanuly (ibid.) states, the linguistic situation of the northern region (Astana city, Akmola, Kostanay, Pavlodar, and northern Kazakhstan in gen- 
eral) is characterised by a number of peculiarities expressed in such indices as national language competence, monolingualism, bilingualism, and multilingualism.

National language competence in the republic is $90.2 \%$, while for the northern region it is $82.4 \%$; monolingualism is $46.2 \%$ and $55.3 \%$ respectively; and bilingualism and multilingualism are $53.8 \%$ and $43.8 \%$ respectively; finally official language competence is $64.4 \%$ and $43.3 \%$ respectively. Having analysed in detail the researched issues individually by region, and in comparison with the indices for the republic in general, Khasanuly reveals the following: the share of monolingualism is directly proportional to the share of the Russian population within the ethnic composition of the northern region, and vice versa, with a decrease in the share of Russians in the ethnic composition the indices of bilingualism and multilingualism increase (Khasanuly 2002: 38-39).

From the aspect of contrastive linguistics, E. Suleimenova investigates the problems of bilingualism, the main trends in the development of Kazakh and Russian, the question of the cognitive, creative, and pedagogical aspects in the development and existence of the individual in a second language, and the peculiarities of the present linguistic situation in Kazakhstan with reference to the policy of linguistic renaissance (Suleimenova 1996, 2011a; Suleimenova \& Smagulova 2005; Suleimenova et al. 2007). Suleimenova uses theories of language vitality to analyse the sociolinguistic situation of Kazakh. The researcher monitors the impact of the republic's language policy on the functional development of the official language and has made a detailed analysis of the status and usage of Kazakh as the official language. Moreover, she has studied the functional correlation of the usage of Kazakh (as the official language) and Russian within the existing common space. Her special interest is in the quantitative and qualitative aspects of language policy in Kazakhstan in recent years. In her analysis, Suleimenova pays attention to how linguistic, social, political, demographic, ethnic, and cultural parameters can theoretically increase the vitality of Kazakh. Suleimenova has assessed the language policy of Kazakhstan on the basis of wide-ranging research as:

- centralised (as it is implemented by the government, which provides a system of required measures);

- perspective (as it is directed to change the present linguistic situation);

- democratic (as it considers the interests of broad masses);

- international (as the development of Kazakh and Russian, and the languages of other ethnic groups, has been chosen as the main strategic direction);

- constructive (as it is directed to the expansion of the sphere of usage, the social and communicative role and vitality of the Kazakh language, and to the support of Russian and other languages in the country); 
- exoglossic (as in spite of strong purist tendencies in Kazakh, an international lexis has been developing, as well as a lexis that serves communication within the new spheres of information and technology) (Suleimenova 2011a: 49).

The research devoted to the study of bilingualism allows us to provide an objective picture of the linguistic situation in the country, which, in turn, is the determining factor for the development of bilingualism, which itself influences the process of second language acquisition and productive implementation of bilingual communication in different fields.

The linguistic situation in Kazakhstan has changed under the influence of various factors: Kazakh has acquired the status of the official language. A state programme for the development of languages was implemented, directed to the restoration of the functions of Kazakh in all public fields. This programme was also to provide linguistic and methodological support for the process of official language teaching. The authors of this paper have noticed positive changes in the modern linguistic situation of the republic: an obvious shift in the mastery of Kazakh by the Russian population (1,322,270 people were studying Kazakh in 2000) (Khasanov 2001: 221), the beginning of a new everyday Russian-Kazakh bilingualism not limited by the bilingualism of the classroom, and the beginning of Russian-Kazakh bilingualism in business communication (Akhmetzhanova 2001). However, despite the positive results of the on-going language policy and language planning (the development and production of scientific and methodological literature on the Kazakh language intended for foreign-speaking citizens, active work on the unification of scientific terminology, the expansion of programme broadcasting in Kazakh, attempts to optimise the teaching of Kazakh at all levels of the education system, the implementation of projects for the gradual transition to business in Kazakh, the productive activity of the Centre for the Accelerated Learning of the Official Language, which aims to train state officers, etc.), the problems involved in the proper functioning of Russian-Kazakh bilingualism require a more purposeful development.

The studied peculiarities of the modern linguistic situation undoubtedly influence the process of Kazakh language learning and usage. In order to study the effects of socio-psychological and demographic factors on the acquisition and use of Kazakh, A. Agmanova conducted a questionnaire among university students and government employees who were studying Kazakh at the Centre for Accelerated Learning of the Official Language. ${ }^{2}$ Survey data give evidence that demographic, social, and psychological factors correlate with the level of official language competence and the fields of its usage. It was revealed that among non-indigenous ethnic groups integrative and instrumental motivation 
to learn the official language increased. The dominance of a particular language during the pre-education period, and the language used in the family, affect the preservation and level of language competence. The questionnaire also helped to identify the strategic settings of the study and usage of the official language, and the problems that the learners encounter. The results are also of interest in terms of didactics, as they can be the basis for determining those learning strategies that give maximum consideration to all factors that affect the acquisition of Kazakh as a second language by the Russian-speaking population (Agmanova 2010).

The research of E. Zhuravleva $(2009,2010)$ focuses on the Russian language as a polynational phenomenon that can form national variants, included the Kazakhstan variant. For that she studied the most important functions and spheres of Russian language usage. The results of sociolinguistic research into the Kazakh variant of Russian were described, with the main task to identify the cultural component of language competence of the Russian language speaker's personality in Kazakhstan: the complex of knowledge and understanding of cultural phenomena, political and social realities, precedential names, etc.

As Zhuravleva states, languages that have several centres of development can establish different national variants due to their separate language processes, separate norms, and definite official statuses. She calls such languages polynational. Their differences are characterised by the 'national variability'. A national variant is a form of adaptation of a literary language to the conditions, needs, and traditions of a nation. In other words, a national variant is a specific form of the literary language that functions as an independent "community of communication" within a nation (Zhuravleva 2010). Within Kazakhstan, active language contacts, interethnic integration, legal status (according to the Constitution of the Republic of Kazakhstan, Russian is a language of international communication), and a scale of how Russian functions in all the fields of official and public life allow us to consider Russian as polynational.

Zhuravleva states:

The areas of Russian language usage in Kazakhstan form a specific sociofunctional model that is a complex of existing language forms, within which the speaking needs of the community in all life situations and the ability to consider Kazakh Russian one of polynational variants are implemented. (Zhuravleva 2009: 70)

The study results show a definite picture of Russian and the changes occurring in it. Thus, the influence of Kazakh on Russian is manifested both orally and in written form (texts that include Kazakh language units are very common). 
Media texts contain a variety of 'inserts' in Russian (text) of different language elements from the contacting system. This forms a lexis that reflects the political structure of Kazakhstan (akim - the governor, mayor of the city or region; tenge - the national currency of Kazakhstan; etc.); national holidays celebrated in Kazakhstan and everything related to them (Nauryz - Eastern New Year celebrated on March 22nd mainly in Asian countries; Nauryz-kozhe - a meal prepared specially for Nauryz which has 7 different ingredients: water, meat, salt, milk or yoghurt, one type of grain, chosen from rice, corn, or wheat, and others; etc.); everyday life (piala - a drinking bowl; chapan - a coat worn over clothes during cold winter months; etc.); the names of dishes (baursak - a type of fried dough food, found in the cuisine of Central Asia; it is usually compared to doughnut; beshparmak - national dish among nomadic Turkic people, boiled meat mixed with boiled noodles; etc.); religious rites (sadaka - a compulsory charity in Islam; ramazan - the ninth month of the Islamic calendar, a month of fasting and commemorating the first revelation of the Quran to Muhammad; etc.); national traditions (bessike saly - a holiday, hosted when the newborn is put to a cradle (besik); syinshi - a custom according to which a traveller or any other person who brought home a good message (news) receives a valuable gift from the owners in gratitude); the field of music (aitys - a contest between two improvisators-songwriters popularly called akyns; dombyra - a Kazakh stringed musical instrument played by plucking, with a wooden frame (its length is 1000-1300 millimetres) and two strings; etc.); sport (kyzkuy - literally 'bride chasing', an equestrian traditional sport among the Azerbaijanis, Kazakhs, and Kyrgyz; kokpar - a Central Asian sport in which horse-mounted players attempt to drag a goat or calf carcass toward a goal; etc.); toponyms (cities - Astana, Aktau, Atyrau, Kokshetau, and others; rivers and lakes Essil, Burabai, and others; mountains - Zhumbaktas, Okzhetpes, and others); anthroponyms, as well as the units of other fields (Zhuravleva 2010). To refer to the relevant linguistic units in Russian in Kazakhstan, the term 'regionalism' was adopted in those cases where these units are either in opposition to vernacular literary standards, or expand their boundaries. The vocabulary of the Kazakhstani variant of Russian is representative of all national varieties, i.e., it is composed of three main layers: "the vocabulary of the literary level, the vocabulary of everyday colloquial lexical items, and, much more rarely, dialect words" (Zhuravleva 2009: 72).

When used in a Russian text, similar lexical units from another language are used as the units of 'another' but simultaneously 'its own' (i.e. 'not foreign') code. Thus, the function of the lexical items is fixed as normal language practice.

Critical discourse analysis based on the study of state documents, the speeches of politicians, public activists, teachers, representatives of the mass media, 
and the results of interviews and questionnaires allowed Kazakhstani research (Zharkynbekova \& Aimoldina 2012) to define the attitude of the country's citizens towards the policy of trilingualism ${ }^{3}$. According to this, the three vectors of language policy are the most important to ensure worthy compliance with international standards of development: along with two functioning languages (Kazakh as the only official language and Russian widely used as a language of international communication), the English language becomes more and more popular, which is considered as one of the basic conditions for successful integration into the global economy.

Scholars have noted the positive aspects of the interaction of three language systems also for public employees, who, by analysing and comparing the three languages, will have the opportunity not only to convey information better, but also to think in terms of three cultures and values.

As was defined, the policy of trilingualism positively influences the harmonic development of a personality (74.9\%), leads to the position of Kazakh being strengthened (68.5\%), and strengthens the position of the English language (61.2\%) (Zharkynbekova \& Aimoldina 2012).

However, the wide spread of English sharpened the contradictions of the modern language system and intensified its dynamics. Some groups of the population, however, reacted negatively to the increasing popularity of English. From the very beginning, some community representatives saw in the idea of the project a risk for the development of other languages, especially the official language. Others consider the strengthening of English in Kazakhstan as an attempt to oust Russian. The remainder state that the spread of English in Kazakhstan might negatively affect the development of minority languages. Foreign experts consider the introduction of the programme to have been premature.

A. Agmanova, D. Akynova, and A. Akzhigitova (2012) devoted their research to the study of the issues related to language preference among ethnic minority groups and immigrants in Kazakhstan. The data they have gathered shows a positive attitude towards English in the immigrants' environment, which can be demonstrated by the following statements: a) English has become increasingly popular in Kazakhstan (85.2\%); b) English language knowledge is prestigious (66.6\%); c) learning English is beneficial in economic terms (74.6\%); d) knowledge of English is an opportunity to get a good job (81.4\%); e) knowledge of the English language allows us to join the world community (85.1\%); f) the use of English has increased in various areas over the past five years $(60.3 \%)$; g) knowing the English language is a sign of the country's competitiveness (75.1\%); h) English should be learnt from grade 1 (81.3\%). The data reflect the immigrants' opinions concerning the perspectives of language development, as 
is shown by the following statements: a) the Kazakh language will inevitably predominate in all areas of society (88.9\%); b) the position of the English language is improving along with that of the Kazakh language (56\%).

The opinion of ethnic minority communities concerning the significance of English in their lives is supported by the following comments: a) English language proficiency is important for further professional development (75\%); b) there is a need to improve one's English language knowledge (72.2\%); English language learning stimulates interest (72.2\%); c) knowing English increases a person's prestige and builds up a sense of self-confidence (38.9\%); d) English language usage has increased in different areas in recent years (63.9\%); e) knowing the English language is a sign of the country's competitiveness (94.5\%); f) English should be learnt from grade 1(72.2\%). Thus, a vast majority of respondents connect their further professional development with knowledge of English; English language proficiency is considered by them to be one of the essential factors influencing the opportunities to improve one's career.

\section{CONCLUSION}

One of the important methodological foundations of modern Kazakhstani research is the peculiarity of the linguistic situation in Kazakhstan, which creates a prerequisite for a comprehensive, systematic study of activities that focus on the optimisation of social communication.

The data from the research mentioned above shows the effectiveness of the policy of extending the areas of the official language, supporting the function of Russian, and promoting English within the trilingualism project.

The studying of processes of ethno-linguistic identification allows us to define a circle of problems that exist today within the framework of a new government language policy. Problems such as Soviet-period inheritance are related to the modern political and economic situation in the world in general, and in the territory of the former Soviet Union in particular. Solving these problems will create the opportunity to contribute to the implementation of the idea of a peaceful co-existence of the ethnic communities in the territory of Kazakhstan, as well as their languages, and to facilitate support for the increasing interest of the diaspora in their native language, culture, traditions, and customs, all of which have a positive impact on preserving ethnic originality.

Thus, the polyethnic culture and society of Kazakhstan, a unique feature of the mentality and interests of each ethnic community, create a specific sociocultural context for different aspects of research into identity issues in modern linguistics. 
The methodology used in this study allows us to follow the implementation of the language planning programmes in the Republic of Kazakhstan, as well as the implementation of the priorities of the State Programme for the Functioning and Development of Languages for 2011-2020.

The sociolinguistic research considered here focuses on identifying the essence and role of languages in ethno-cultural interrelation and gives important information for the timely correction of the language policy and language planning; it is also useful for working towards solutions in the field of language regulation.

\section{NOTES}

1 Basic directions of the language policy of sovereign Kazakhstan, which meet the needs of the polyethnic population and consider the peculiarities of demographic and political situation are reflected in the principal legislations of the Republic of Kazakhstan, the Constitution of the Republic of Kazakhstan (Articles 7, 93) (Constitution), the Law on Languages of the Republic of Kazakhstan (Law 1999), and the decrees and annual addresses of the country's president, N. Nazarbayev. During the years of sovereignty three state programmes for the functioning and development of languages have been adopted. The first one - the State Programme for the Functioning and Development of Languages in the Republic of Kazakhstan for the Years 1998-2000 (State Programme 1998) - formed legal frameworks of linguistic construction in the main fields of the country's public life; the second one - the State Programme for the Functioning and Development of Languages in the Republic of Kazakhstan for the Years 2001-2010 (State Programme 2001) - strengthened the achieved results in three directions: the social and communicative functions of the official language were significantly reinforced, the general cultural function of Russian was reserved, and the development of the other languages of the peoples of Kazakhstan was supported. During the same period the cultural project Tripartite Unity of Languages was implemented by the initiative of the country's leader (Nazarbayev 2007). Currently, the State Programme for the Functioning and Development of Languages in the Republic of Kazakhstan for the Years 2010-2020 is also being implemented, having been adopted by Presidential Decree No. 110, from June 29, 2011 (State Programme 2011). The aim of the programme is a harmonic language policy that ensures the full functioning of the official language as the most important factor in strengthening national unity, while maintaining all the languages of ethnic groups living in Kazakhstan.

2 The Republican Centre for Accelerated Learning of the Official Language was founded in accordance with the Presidential Decree from June 19, 1995, No. 2335, On State Organisation, aimed at organising systems of intensive learning of Kazakh by state officers. The main objective of the centre is to manage all the necessary organising, material, and technical conditions, as well as training and the scientific provision of intensive learning of Kazakh for state officers.

3 The implementation of the cultural project Tripartite Unity of Languages was officially launched by a Presidential Decree in 2007 (Address to the People of Kazakhstan, titled New Kazakhstan in a New World; Nazarbayev 2007). 


\section{REFERENCES}

Agmanova, Atirkul 2010. Ekstralingvisticheskie faktory usvoeniia vtorogo iazyka. [Extra-Linguistic Factors of a Second Language Acquisition.] Vestnik KarGU: Seriia filologicheskaia. [Bulletin of Karaganda State University: Philological Series.] Vol. 4, pp. 4-9. Available at http://articlekz.com/article/6420, last accessed on January 18, 2016.

Agmanova, Atirkul \& Akynova, Damira \& Akzhigitova, Assel 2012. Iazykovoe predpochtenie i otnoshenie $\mathrm{k}$ prodvizheniiu angliiskogo iazyka sredi grupp etnicheskikh men'shinstv i immigrantov v Kazakhstane. [Language Preferences and Attitudes towards the Promotion of English amongst Ethnic Minority and Immigrant Communities in Kazakhstan.] In: Sh. Zharkynbekova (ed.) Sofunktsionirovanie iazykov v polikul'turnom prostranstve Kazakhstana: kollektivnaia monografiia. [Co-Functioning of Languages in Polycultural Landscape of Kazakhstan.] Monograph. Astana: WOWprint.kz, pp. 105-156.

Akhmetzhanova, Zauresh 2001. O iazykovoi situatsii v Kazakhstane. [Linguistic Situation in Kazakhstan.] Russkii iazyk v sotsiokul'turnom prostranstve XXI v.: Materialy mezhdunarodnoi konferentsii. [Russian Language in Socio-Cultural Space in the 21st Century: Conference Proceedings.] Almaty: Kazakhskii gosudarstvennyi natsional'nyi universitet im. al'-Farabi, p. 221.

Altynbekova, Olga 2006. Etnoiazykovye protsessy v Kazakhstane. [Ethno-Linguistic Processes in Kazakhstan.] Almaty: Ekonomika.

Dave, Bhavna \& Sinnott, Peter 2002. Demographic and Language Politics in the 1999 Kazakhstan Census. Washington, D.C.: National Council for Eurasian and East European Research. Available at https://www.ucis.pitt.edu/nceeer/2002-815-01gDave.pdf, last accessed on January 19, 2016.

Dosanova, Albina 2011. Repatriant-qazaqtardyng tildik beiimdelui. [Linguistic Identification of the Kazakh Repatriates.] Abstract of dissertation (PhD thesis). Almaty: Areket Print.

Gazdieva, Bella 2009. Funktsionirovanie rodnogo iazyka ingushskoi diaspory v usloviiakh russko-kazakhskogo bilingvizma. [Functioning of the Ingush Diaspora's Native Language in Russian-Kazakh Bilingualism.] Diss. (Candidate of Philosophy). Kokshetauskii gosudarstvennyi universitet im. Sh. Sh. Ualikhanova.

Isaev, Mukhamedjan 1990. Dinamika foneticheskoi interferentsii pri formirovanii kazakhsko-angliiskogo bilingvizma. [Dynamics of Phonetic Interference in KazakhRussian Bilingualism Formation.] Almaty: Nauka KazSSR.

Karlinskii, Avram 1989. Eksperimental'noe izuchenie leksicheskoi interferentsii v prikladnykh tseliakh. [Experimental Study of the Lexical Interference in the Applied Purposes.] Sravnitel'no-sopostavitel'noe izuchenie iazykov i interferentsiia. [Comparative-Contrastive Language Study and Interference.] Almaty: KazGU, pp. 51-60. Available at http://www.booksite.ru/fulltext/sranvsopost/text.pdf, last accessed on January 19, 2016.

Karlinskii, Avram 1990. Osnovy teorii vzaimodeistviia iazykov. [The Bases of Languages Interrelation Theory.] Almaty: Gylym.

Karlinskii, Avram 2001. Dvuiazychie i mezhetnicheskaia kommunikatsiia. [Bilingualism and Interethnic Communication.] Aktual'nye problemy mezhkul'turnoi kommu- 
nikatsii i perevoda. [Topical Issues of Intercultural Communication and Translation.] Almaty: KazTUMOiMIa im. Abylaikhana, pp. 253-259.

Khasanov, Bakhitjan 1992. Sotsial'no-lingvisticheskie problemy funktsionirovaniia kazakhskogo iazyka v Respublike Kazakhstan. [Social and Linguistic Problems of the Kazakh Language Functioning in the Republic of Kazakhstan.] Abstract of dissertation ( $\mathrm{PhD}$ thesis). Almaty: Kazakhskii gosudarstvennyi natsional'nyi universitet im. al'-Farabi.

Khasanov, Bakhitjan 2001. Russkii iazyk v Kazakhstane: na platforme iazykovogo suvereniteta. [Russian Language in Kazakhstan: On the Platform of Language Sovereignty.] Russkii iazyk v sotsiokul'turnom prostranstve XXI v.: Materialy mezhdunarodnoi konferentsii. [Russian Language in Socio-Cultural Space in the 21st Century: Conference Proceedings.] Almaty: Kazakhskii gosudarstvennyi natsional'nyi universitet im. al'-Farabi, pp. 221-222.

Khasanuly, Baqytzhan 1992. Ana tili - ata mura (qazaq tilining zher zhüzi tilderi zhüiesindegi alatyn orny. [Native Language - Great Gift from Ancestors (The Role of the Kazakh Language in the System of World Languages).] Almaty: Zhazushy.

Khasanuly, Baqytzhan 2002. Aymaq tilderi men memlekettik til qyzmetin arttyrüdyng egemendik tughyrnamasy: ädisnama men monitoring mäseleleri. [Independent Platform of the Regional and Official Language Functioning: Methods and Monitoring Issues.] Kostanay: TOO Tvoy shans.

Kopylenko, Moisei 1997. Sotsial'noe i etnicheskoe v iazyke (ocherk vzaimodeistviia). [Social and Ethnic in a Language (Essay of Interrelation).] In: Oblik slova: Sbornik statei pamiati D.N. Shmeleva. [The Image of a Word: Collection of Works in Memory of D.N. Shmelev.] Moskva: RAN Institut russkogo iazyka, pp. 354-359.

Kopylenko, Moisei \& Saina, Saaia 1982. Funktsionirovanie russkogo iazyka v razlichnykh sloiakh kazakhskogo naseleniia. [Russian Language Functioning in Different Layers of the Kazakh Population.] Almaty: Nauka.

Krysin, Leonid 1992. O perspektivakh sotsiolingvisticheskikh issledovanii v rusistike. [Perspectives of Sociolinguistic Researches in Russian Studies.] Rusistika, Vol. 2, pp. 96-106. Available at http://www.philology.ru/linguistics2/krysin-92.htm, last accessed on January 14, 2016.

Nazarbayev, Nursultan 2007. New Kazakhstan in New World: Address of the President of the Republic of Kazakhstan, Nursultan Nazarbayev, to the People of Kazakhstan, February 28, 2007. Available at http://www.akorda.kz/ en/addresses/addresses_of_president/page_address-of-the-president-of-therepublic-of-kazakhstan-nursultan-nazarbayev-to-the-people-of-kazakhstanfebruary-28-2007_1343986887, last accessed on January 19, 2016.

Pak, Nelly 2004. Problema ischeznovaniia minoritarnykh iazykov. [Problems of Endangered Minority Languages.] Abstract of dissertation ( $\mathrm{PhD}$ thesis). Almaty: Kazakhskii universitet mezhdunarodnykh otnoshenii i mirovykh iazykov imeni Abylai khana. Available at http://cheloveknauka.com/problema-ischeznoveniyaminopitapnyx-yazykov, last accessed on January 19, 2016.

Sancak, Meltem \& Finke, Peter 2005. Migration and Risk Taking: A Case Study from Kazakhstan. In: Lillian Trager (ed.) Migration and Economy: Global and Local Dynamics. Walnut Creek \& Lanham \& New York \& Oxford: AltaMira Press, pp. 127-161. 
Shaibakova, Damina 1999. Funktsionirovanie russkogo iazyka v Kazakhstane. [Russian Language Functioning in Kazakhstan.] Mir iazyka: Materialy mezhdunarodnoi konf., posviashchennoi pamiati prof. M.M. Kopylenko. [The World of Language: Materials of the Conference in Memory of Prof. M.M. Kopylenko.] Almaty: KazGUMOiMIa, pp. 115-119.

Smailov, Alikhan (ed.) 2010. Itogi Natsional'noi perepisi naseleniia Respubliki Kazakhstan 2009 goda. [The Results of the 2009 Population Census in the Republic of Kazakhstan.] Astana: Statistics Agency of the Republic of Kazakhstan.

Son, Svetlana 1999. Sotsiolingvisticheskii analiz funktsionirovaniia kore mar i russkogo iazyka v koreiskoi diaspore Kazakhstana. [Sociolinguistic Analysis of the Functioning of Kore-Mar and Russian Languages in the Korean Diaspora in Kazakhstan.] Abstract of dissertation (PhD thesis). Almaty: Kazakhskii gosudarstvennyi natsional'nyi universitet im. al'-Farabi.

State Programme 1998 = Gosudarstvennaia programma funktsionirovaniia i razvitiia iazykov. [State Programme for the Functioning and Development of Languages.] Available at http://kazakhstan.news-city.info/docs/sistemsb/dok_oeqytz.htm, last accessed on January 21, 2016.

State Programme 2001 = Gosudarstvennaia programma funktsionirovaniia $i$ razvitiia iazykov na 2001-2010 gody. [State Programme for the Functioning and Development of Languages for the Years 2001-2010.] Available at http://adilet. zan.kz/rus/docs/U010000550_, last accessed on January 21, 2016.

State Programme 2011 = Gosudarstvennaia programma funktsionirovaniia $i$ razvitiia iazykov na 2011-2020 gody. [State Programme for the Functioning and Development of Languages for the Years 2011-2020.] Available at http://adilet. zan.kz/rus/docs/U1100000110, last accessed on January 21, 2016.

Suleimenova, Eleonora 1996. Kazakhskii i russkii iazyki: osnovy kontrastivnoi lingvistiki. [Kazakh and Russian Languages: The Bases of Contrastive Linguistics.] Almaty: Demeu.

Suleimenova, Eleonora (ed.) 1997. Iazykovaia politika v Kazakhstane (1921-1997): Sbornik dokumentov. [Language Policy in Kazakhstan (1921-1997): Collection of Documents.] Almaty: Kazakh Universitet.

Suleimenova, Eleonora 2007. Arkhetip "gadkogo utenka” i iazykovaia identichnost'. [Archetype of 'Ugly Duckling' and Linguistic Identity.] Prezidium MAPRIaL: Sbornik nauchnykh trudov. [Presidium of International Association of Russian Language and Literature Teachers: Collection of Research Articles.] Sankt Peterburg: MIRS, pp. 280-290.

Suleimenova, Eleonora 2010a. Tempora mutantur, et nos mutamur in illis: Etnicheskaia i iazykovaia identichnost'. [Tempora mutantur, et nos mutamur in illis: Ethnic and Linguistic Identity.] In: E. Suleimenova (ed.) Dinamika iazykovoi situatsii v Kazakhstane. [The Dynamics of the Language Situation in Kazakhstan.] Almaty: Lingua, pp. 122-164.

Suleimenova, Eleonora 2010b. Krizis etnicheskoi i iazykovoi identichnosti. [Crisis of Ethnic and Linguistic Identity.] In: E. Suleimenova (ed.) Dinamika iazykovoi situatsii $v$ Kazakhstane. [The Dynamics of the Language Situation in Kazakhstan.] Almaty: Lingua, pp. 165-180. 
Suleimenova, Eleonora 2010c. Glavnyi vektor grazhdanskoi identichnosti. [Main Vector of Civil Identity.] In: E. Suleimenova (ed.) Dinamika iazykovoi situatsii v Kazakhstane. [The Dynamics of the Language Situation in Kazakhstan.] Almaty: Lingua, pp. 48-66.

Suleimenova, Eleonora (ed.) 2010d. Dinamika iazykovoi situatsii v Kazakhstane. [The Dynamics of the Language Situation in Kazakhstan.] Almaty: Lingua.

Suleimenova, Eleonora 2011a. Iazykovye protsessy i politika. [Language Processes and Politics.] Almaty: Kazakh Universitet. Available at http://edu-resource.net/ images/docs/NonyePostupleniya/Suleimenova-Yazykovye_processy_i_politika. pdf, last accessed on January 21, 2016.

Suleimenova, Eleonora 2011b. Makrosotsiolingvistika. [Macro-Sociolinguistics.] Almaty: Kazakh Universitet.

Suleimenova, Eleonora \& Smagulova, Zhuldyz 2005. Iazykovaia situatsiia i iazykovoe planirovanie $v$ Kazakhstane. [Language Situation and Language Planning in Kazakhstan.] Almaty: Kazakh Universitet.

Suleimenova, Eleonora \& Shaimerdenova, Nursuly \& Smagulova, Zhuldyz \& Akanova, Dana 2007. Slovar' sotsiolingvisticheskikh terminov. [Glossary of Sociolinguistic Terms.] Almaty: Kazakh Universitet.

Tezekbayev, Mukatai 1987. Leksicheskaia interferentsiia kazakhskogo iazyka v russkoi rechi kazakhov-bilingvov. [Lexical Interference of the Kazakh Language in the Russian Speech of the Kazakhs-Bilinguals.] Abstract of dissertation ( $\mathrm{PhD}$ thesis). Alma-Ata: KazNU.

Tezekbayev, Mukatai 1998. Rodnoi iazyk kak komponent dvuiazychiia i iazykovaia situatsiia. [Native Language as a Component of Bilingualism and Linguistic Situation.] Problemy teoreticheskogo i prikladnogo iazykoznaniia: Materialy nauchnoi konferentsii KazGUMOiMIa. [The Issues of Theoretical and Applied Language Study: Conference Proceedings.] Almaty: KazGUMOiMIa, pp. 81-85.

Zharkynbekova, Sholpan \& Aimoldina, Aliya 2012. Iazykovoe predpochtenie i natsional'no-gosudarstvennoe stroitel'stvo v Respublike Kazakhstan. [Language Preferences and National State Building in the Republic of Kazakhstan.] In: Sh. Zharkynbekova (ed.) Sofunktsionirovanie iazykov v polikul'turnom prostranstve Kazakhstana: Kollektivnaia monografiia. [Co-Functioning of Languages in the Polycultural Landscape of Kazakhstan: Collective Monograph.] Astana: WOWprint.kz, pp. 65-104.

Zharkynbekova, Sholpan \& Bokaev, Bauyrzhan 2011. Protsessy iazykovoi $i$ etnicheskoi identifikatsii repatriantov Kazakhstana. [The Processes of Linguistic and Ethnic Identification of the Repatriates of Kazakhstan.] Astana: NTs NTI.

Zhuravleva, Evgeniia 2009. K probleme natsional'noi variativnosti iazykov: osobennosti razvitiia russkogo iazyka v Kazakhstane. [To the Problem of National Variety of Languages: Specific Development of the Russian Language in Kazakhstan.] Postsovetskoe prostranstvo. Evraziiskaia ideia $v$ XXI veke: novyi vektor razvitiia. [Post-Soviet Space: Eurasian Idea in the 21st Century: New Vector of Development.] EvroAziia, Vol. 4, pp. 69-79. Available at http://ia-centr.ru/expert/4124/, last accessed on January 21, 2016. 
Zhuravleva, Evgeniia 2010. Protsessy razvitiia russkogo iazyka v stranakh postsovetskogo prostranstva. [Processes of Russian Language Development in the Countries of Post-Soviet Space.] Russkii iazyk: istoricheskie sud'by i sovremennost'. IV Mezhdunarodnyi kongress issledovatelei russkogo iazyka. [The Russian Language: Historical Destinies and Modernity. Conference Proceedings. Moskva: MGU, pp. 653-654. Available at http://www.philol.msu.ru/ rlc2010/abstracts/rlc2010_ abstracts_sec18.pdf, last accessed on January 22, 2016.

\section{INTERNET SOURCES}

Constitution $=$ Constitution of the Republic of Kazakhstan. Available at http://www. akorda.kz/en/official_documents/constitution, last accessed on March 14, 2016.

Law 1999 = Law of the Republic of Kazakhstan on Languages. Available at http://www. usefoundation.org/view/780, last accessed on March 14, 2016. 